\title{
Nipple reconstruction using a two-step purse-string suture technique
}

\author{
Nancy Van Laeken MD FRCSC ${ }^{1,2}$, Krista Genoway MD ${ }^{1}$
}

N Van Laeken, K Genoway. Nipple reconstruction using a two-step purse-string suture technique. Can J Plast Surg 2011;19(2):56-59.

Formation of an aesthetic nipple areola complex with lasting projection remains a challenging final step in breast reconstruction. Despite the many techniques that have been described, no single approach has emerged as the gold standard. The current study presents a novel technique in nipple areola complex reconstruction. In a two-step fashion, the nipple and areola are reconstructed independently. This aims to create a lasting projection of the nipple while maintaining a natural contour among the nipple, the areola complex and the surrounding breast tissue. With more than 15 years of experience using this technique, the authors believe that it is a straightforward procedure and is reliable in providing satisfactory results to both the surgeon and the patient.

Key Words: Areola; NAC; Nipple reconstruction; Purse-string suture

\section{La reconstruction du mamelon au moyen d'une technique de suture en bourse en deux phases}

\begin{abstract}
La formation d'un complexe esthétique d'aréole du mamelon assorti d'une projection durable demeure une étape finale difficile de la reconstruction mammaire. Malgré les nombreuses techniques décrites, aucune démarche unique n'émerge comme la norme. La présente étude expose une nouvelle technique de reconstruction complexe de l'aréole du mamelon. En deux phases, le mamelon et l'aréole sont reconstruits de manière indépendante, afin de créer une projection durable du mamelon tout en maintenant un contour naturel du mamelon, du complexe de l'aréole et des tissus environnants. Les auteurs possèdent plus de 15 ans d'expérience dans l'utilisation de cette technique qui, selon eux, est simple et fiable et donne des résultats satisfaisants à la fois pour le chirurgien et pour le patient.
\end{abstract}

C reation of the nipple areola complex (NAC) is an important final step in the reconstruction of the female breast following mastectomy. Generally, this procedure occurs three to four months following creation of the breast mound and can be performed effectively and safely under local anesthesia on an outpatient basis (1). Although a minor procedure, the final appearance of the NAC has a significant impact on the overall aesthetics of the reconstructed breast. Many authors identify the NAC as the defining component of the female breast (2).

Since first documented by Adams (3) in 1949, many techniques have been used for the reconstruction of the NAC. These techniques have included the star flap, skate flap, arrow flap, tab flap, S-flap, C-V flap, cylindrical flap, H-flap and pinwheel flap, among others (4-12). Regardless of the technique used, the primary goal of NAC reconstruction is the attainment of symmetry in nipple position, shape, size, pigmentation and texture $(1,13,14)$.

Currently, the majority of surgeons use various forms of either a single or double subdermal pedicled flap in combination with skin grafting and tattooing to recreate the NAC (1). Despite the myriad of techniques in nipple reconstruction, no single approach has emerged as the gold standard. Loss of nipple projection and gradual flattening of the NAC continues to remain problematic with currently used techniques (15-17). With that in mind, the current study presents a NAC reconstruction technique that aims to create a symmetrical, well-projected nipple.

\section{SURGICAL TECHNIQUE}

The technique described has evolved over the past 15 years of clinical practice. The patients are marked preoperatively in the upright position to identify the proper positioning of the new NAC on the reconstructed breast. At this time, there are often small adjustments to the breast mounds to help improve symmetry.

To create a three-dimensional nipple reconstruction, the areola and nipple must be elevated. The technique has been designed to create this three-dimensional complex with a gradation in elevation between the areola and the nipple itself.
In the operating room, the areola and nipple are marked on the reconstructed breast. Under general or local anesthetic, the areas for nipple reconstruction are infiltrated with $0.5 \%$ xylocaine with $1: 200,000$ adrenaline. A skin graft is used for areola reconstruction. Currently, the most commonly used site is the lateral aspect of the mastectomy scar or the lateral aspect of the abdominal incision, if transverse rectus abdominis myocutaneous flap reconstruction has been used for breast mound creation.

A full thickness skin graft is harvested in the diameter of $30 \mathrm{~mm}$ to $36 \mathrm{~mm}$ for the desired areola size. The donor site is then closed primarily with $3 / 0$ vicryl and 4/0 monocryl, and the graft is de-fatted and stored in saline.

The areola is then created by de-epithelializing the disc for the areola. This is performed by first incising the outer circumference and then elevating the skin, similar to the de-epithelialization (Figure 1A) that one would perform for an inferior pedicle breast reduction. The central core of the skin graft is left attached to a disc that ranges in diameter from $5 \mathrm{~mm}$ to $10 \mathrm{~mm}$. The diameter of this retained complex is created to match the diameter of the nonoperated breast or to create a suitable-sized nipple complex for the newly created breast. The attached central core of skin acts to provide blood flow to the elevated nipple complex. The areola elevation can then be trimmed depending on the size of the nipple that the surgeon wishes to create and the degree of desired elevation (Figure 1B). It is underscored slightly at the area of retained attachment in the dermis to allow for proper elevation of the nipple complex. A 4/0 suture of merselene is then placed in a purse-string suture around the remaining disc of skin (Figure 1C). This creates an elevated nipple complex because the suture is secured in a purse-string fashion (Figure 1D).

The suture is left in place for six weeks. The now de-epithelialized areola undergoes grafting with the previously harvested full thickness skin graft. It is secured with interrupted sutures of $4 / 0$ ethilon and a running subcuticular suture of 5/0 monocryl placed on the outer circumference of the areola (Figure 2). A hole is fashioned in the middle of the skin graft and the previously created nipple projection is pulled through, creating a three-dimensional nipple complex (Figure 3).

${ }^{1}$ Division of Plastic Surgery, Department of Surgery, University of British Columbia; ${ }^{2}$ Department of Surgery, Providence Health Care, Vancouver, British Columbia

Correspondence: Dr Nancy Van Laeken, Division of Plastic Surgery, Department of Surgery, St Paul's Hospital, Room 350, 1081 Burrard Street,

Vancouver, British Columbia V6Z 1Y6. Telephone 604-806-8575, fax 604-806-9140, e-mail nvanlaeken@providencehealth.bc.ca 

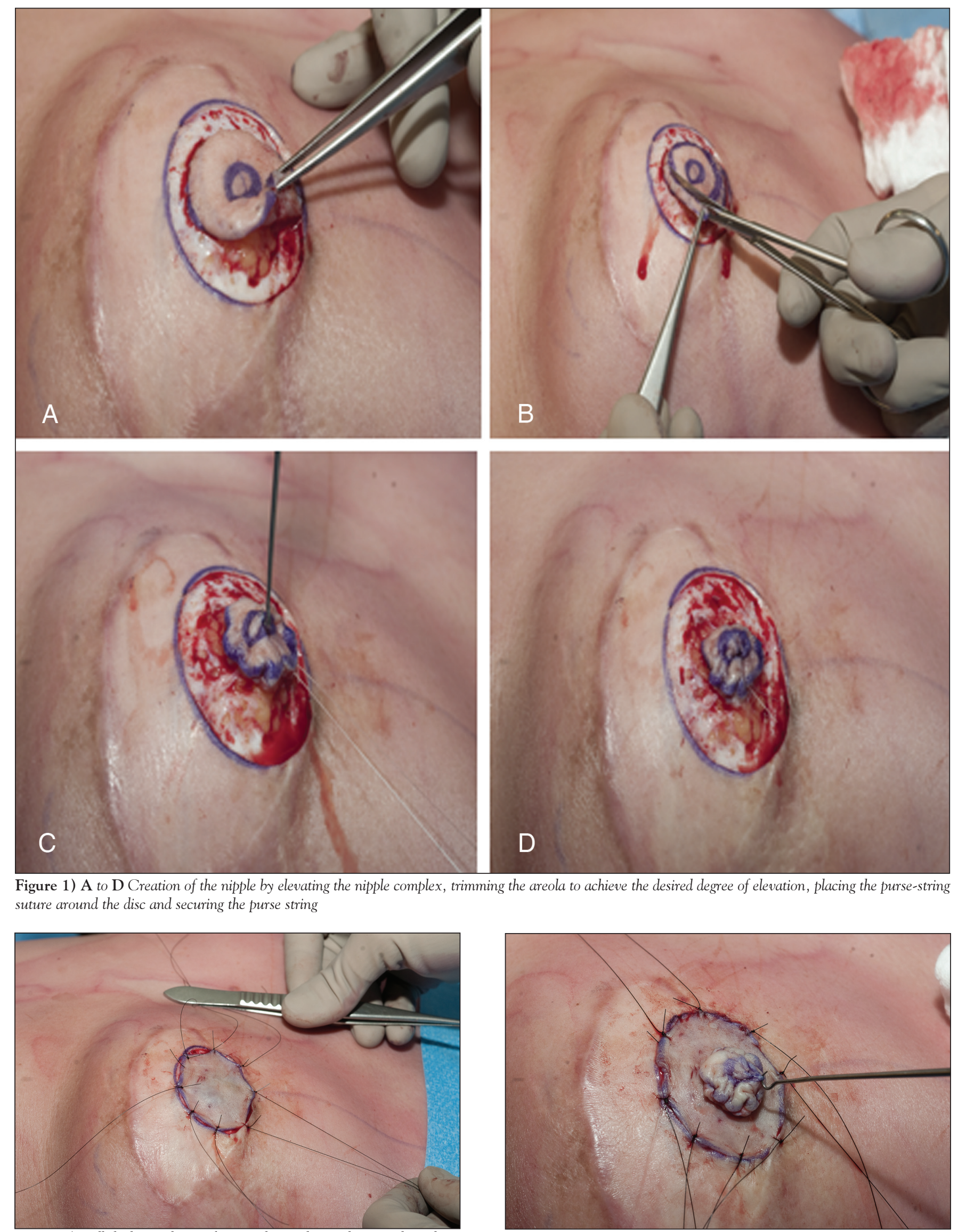

Figure 1) A to D Creation of the nipple by elevating the nipple complex, trimming the areola to achieve the desired degree of elevation, placing the purse-string suture around the disc and securing the purse string

Figure 2) Full thickness skin graft secured over the newly created nipple

graft secured over the newhy created nipple

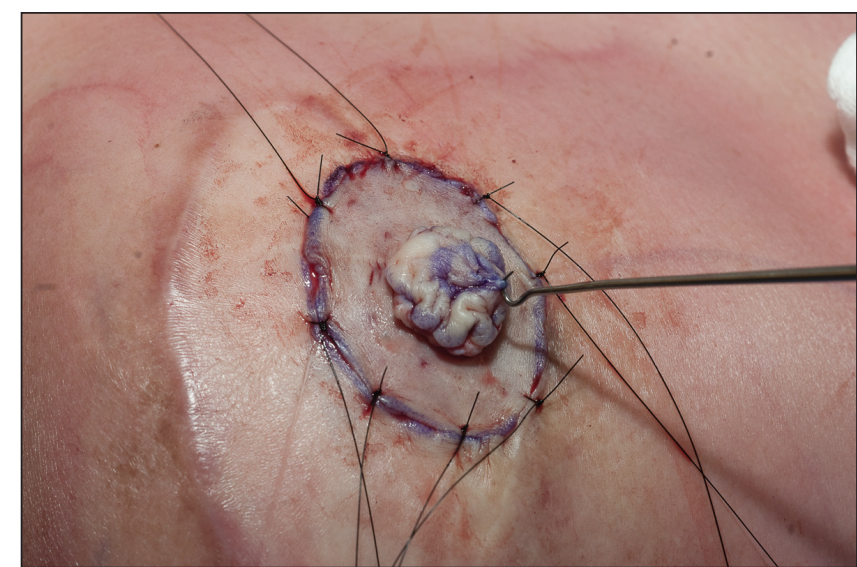

Figure 3) Projection of the newly created nipple through the full thickness skin graft 

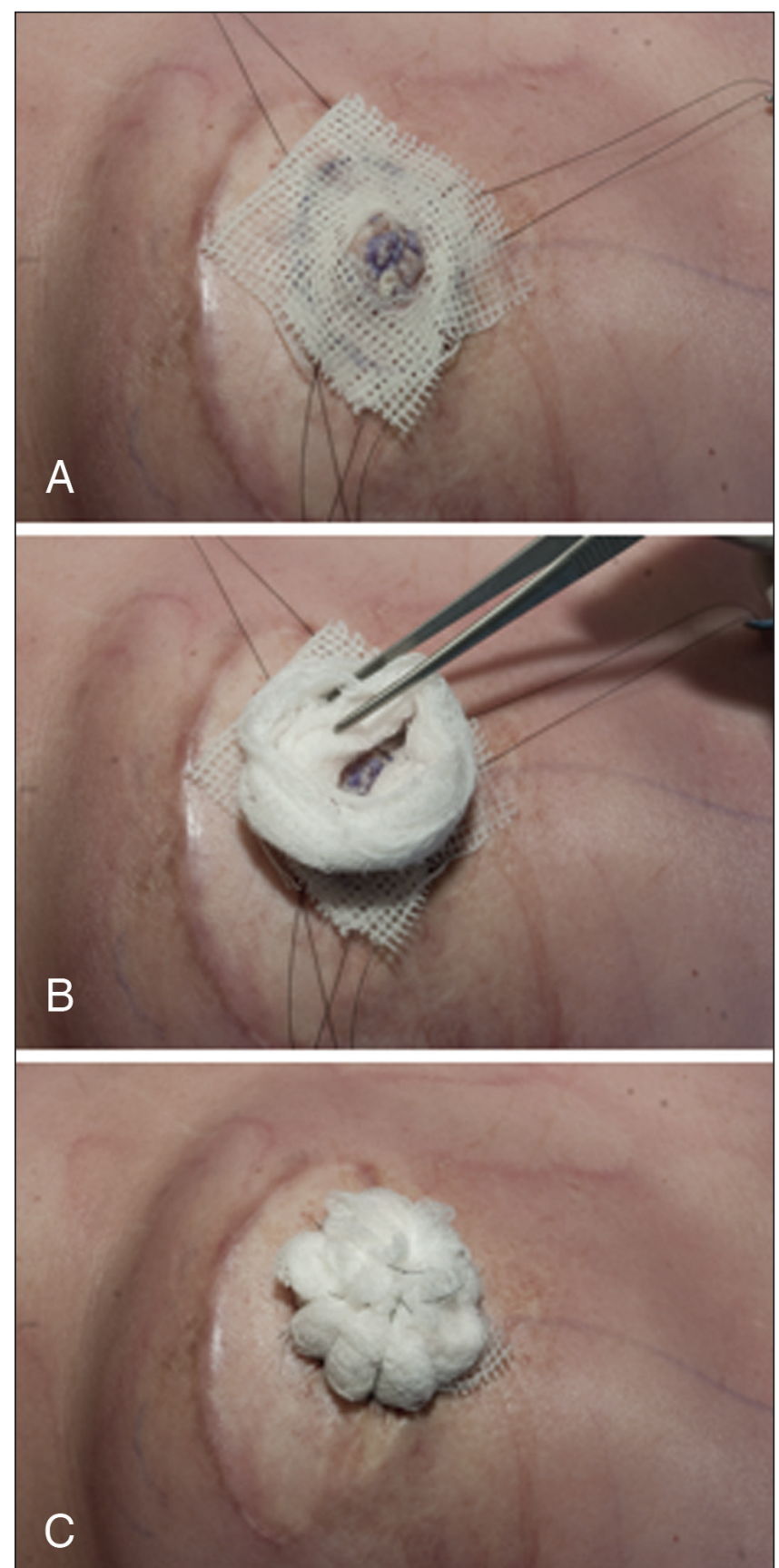

Figure 4) A to C Tie-over Jelonet (Smith $\mathcal{E}$ Nephew Healthcare, UK) dressing with wet-to-dry compresses

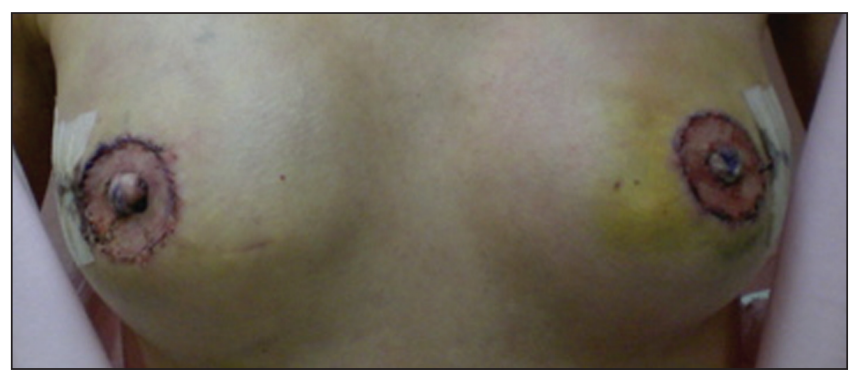

Figure 5) Close-up of the reconstructed nipple areola complex seven days postreconstruction

A tie-over dressing of Jelonet (Smith \& Nephew Healthcare, UK) and wet-to-dry compresses is then secured over the graft to ensure good graft take (Figures $4 \mathrm{~A}, 4 \mathrm{~B}$ and $4 \mathrm{C}$ ). An opening is left in the
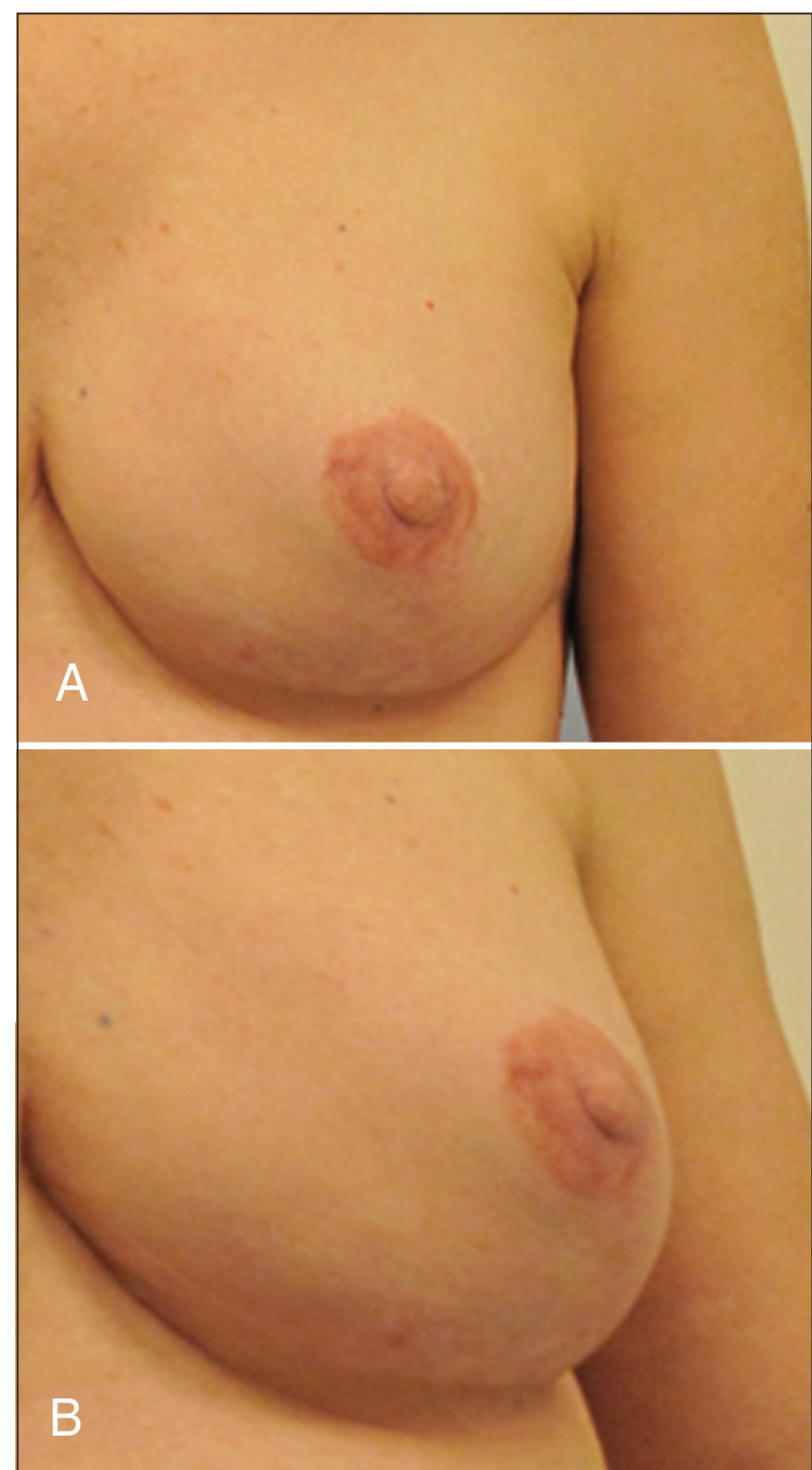

Figure 6) Close-up of the reconstructed nipple areola complex before (A) and four years postreconstruction (B)

central portion of the pressure dressing to allow for nipple projection. This dressing is left in place for seven days, at which time the bandages are removed and another protective dressing is applied for an additional seven days (Figure 5).

Tattooing is completed approximately six months after the surgical reconstruction of the nipple to provide appropriate colour match with the previous nonoperated side. Alternatively, both nipples can be tattooed with the same colour after a bilateral reconstruction (Figures 6A and 6B).

\section{DISCUSSION}

Creation of an aesthetic, well-placed nipple with lasting projection remains a challenging final stage in breast reconstruction (15). A variety of techniques have been described for reconstruction of the NAC. The most popular methods involve the use of local flaps (1). Criticisms of these techniques have included the following: NAC distortion secondary to contractile forces on local tissue during healing, NAC atrophy secondary to loss of adipose tissue and NAC tissue necrosis secondary to a poor vascular supply $(15,17,18)$. All of these postoperative changes have been shown to contribute to loss of nipple projection. In hopes of avoiding this, many authors advocate a strategy of 
'overbuilding' the reconstructed nipple by $25 \%$ to $50 \%(5,19)$. Unfortunately, this approach requires recruitment of additional tissue in the used flaps. This increases the risk of adjacent tissue distortion, resulting in alteration of the final contour and form of the reconstructed breast.

The technique described in the present article aims to maintain long-term nipple projection by creating the nipple and areola complex independent of one another. Intrinsic to the technique, a purse-string suture is used to create projected volume and surface area of the reconstructed nipple (20). The degree of projection can be varied depending on the extent of dermis that is undermined before suture placement. The purse-string suture is left in place for six weeks to provide support to the newly created nipple. This suture is subsequently removed to avoid potential complications of a foreign body.

The vascular supply to the nipple remains unaltered because the central aspect has not been undermined or dissected. This healthy vascular supply minimizes the chance of tissue atrophy and necrosis, which are major factors contributing to the loss of nipple projection $(21,22)$

Following the creation of the nipple, the areola complex is formed using a full-thickness skin graft (FTSG). Creating the nipple and areola separately minimizes local contraction forces on the nipple compared with rotational or advancement flaps, which use a single tissue source. If possible, the FTSG is harvested in the region of a previous scar (ie, a transverse rectus abdominus myocutaneous flap scar). The FTSG is accurately measured and placed over the newly created nipple. This avoids incisions within the region of the areola complex. In addition to avoiding unsightly scarring, we are able to create natural definition among the nipple, the areola and the surrounding breast tissue. All of these factors contribute to the creation of a natural-appearing NAC. A tie-over dressing is left in place for seven days. This provides stability to the reconstructed site while promoting graft take. All patients, however, require tattooing in three to six months for colour match and symmetry.

Graft take is excellent using this technique. However, one must take extreme care when operating on thin and irradiated patients. In such cases, de-epithelialization must be performed superficially to allow for the maintenance of a well-vascularized tissue bed. Even in thin, irradiated patients, we are able to achieve a three-dimensional reconstruction. In such patients, however, the NAC may be more prone to asymmetry when compared with the nonoperated breast. Currently, there is no contraindication to using this technique.

\section{CONCLUSION}

The current article presents a novel technique for NAC reconstruction. In a two-step fashion, a purse-string suture is used to create the nipple while an FTSG is used to reconstruct the areola. This technique in NAC reconstruction is most reliable when a transverse rectus abdominus myocutaneous flap is in place. It is also beneficial to operate on patients with sufficient subcutaneous fat to allow for adequate elevation. Currently, there is no contraindication to using this technique. In our experience, this technique is a straightforward procedure and is reliable in producing a three-dimensional nipple complex that has adequate long-term projection and provides satisfactory results to both the surgeon and the patient.

\section{REFERENCES}

1. Farhadi J, Maksvytyte GK, Schaefer DJ, Pierrer G, Scheufler O. Reconstruction of the nipple-areola complex: An update. J Plast Reconstr Aesthet Surg 2006;59:40-53.

2. Few JW, Marcus JR, Casas LA, Aitken ME, Redding J. Long-term predictable nipple projection following reconstruction. Plast Reconstr Surg 1999;104:1321-4.

3. Adams WM. Labial transplant for correction of loss of the nipple. Plast Reconstr Surg 1949;4:295.

4. Anton MA. Nipple reconstruction with local flaps: Star and wrap flaps. Perspect Plast Surg 1991;5:67.

5. Guerra AB, Khoobehi K, Metzinger SE, Allen RJ. New technique for nipple areola reconstruction: Arrow flap and rib cartilage graft for long-lasting nipple projection. Ann Plast Surg 2003;50:31-7.

6. Weiss J, Herman O, Rosenberg L, Shafir R. The S nipple-areola reconstruction. Plast Reconstr Surg 1989;83:904-6.

7. Cronin TD, Upton J, McDonough JM. Reconstruction of the breast after mastectomy. Plast Reconstr Surg 1977;59:1-14.

8. Little III JW, Munasifi T, McCulloch DT. One-stage reconstruction of a projecting nipple: The quadrapod flap. Plast Reconstr Surg 1983;71:126-33

9. Hallock GG, Altobelli JA. Cylindrical nipple reconstruction using an H flap. Ann Plast Surg 1993;30:23-6.

10. Thomas SV, Gellis MB, Pool R. Nipple reconstruction with a new local tissue flap. Plast Reconstr Surg 1996;97:1053-6.

11. Cohen IK, Ward JA, Chandrasekhar B. The pinwheel flap nipple and barrier areola graft reconstruction. Plast Reconstr Surg 1986;77:995-9.

12. Kroll SS, Hamilton S. Nipple reconstruction with the double-opposing-tab flap. Plast Reconstr Surg 1989;84:520-5.

13. Momeni A, Becker A, Torio-Padon N, Iblher N, Stark GB, Bannasch H. Nipple reconstruction: Evidence-based trials in the plastic surgical literature. Aesthetic Plast Surg 2008;32:18-20

14. Valdatta L, Montemurro P, Tamborini F, Fidanza C, Gottardi A, Scamoni S. Our experience of nipple reconstruction using the C-V flap technique: 1 year evaluation. J Plast Reconstr Aesthet Surg 2009;62:1293-8.

15. Turgut G, Sacak B, Gorgulu T, Yesilada AK, Bas L. Nipple reconstruction with bipedicled dermal flap: A new and easy technique. Aesthetic Plast Surg 2009;33:770-3.

16. Shestak KC, Gabriel A, Landecker A, Peters S, Shestak A, Kim J. Assessment of long-term nipple projection: A comparison of three techniques. Plast Reconstr Surg 2002;110:780-6.

17. Rubino C, Dessy LA, Posadinu. A modified technique for nipple reconstruction: The 'arrow flap'. Br J Plast Surg 2003;56:247.

18. Dolmans GH, Van de Kar AL, Van Rappard JH, Hoogbergen MM. Nipple reconstruction: The "Hammond" flap. Plast Reconstr Surg 2008;121:353-4.

19. Turgut G, Sacak B, Görgülü T, Yesilada AK, Bas L. Nipple reconstruction with bipedicled dermal flap: A new and easy technique. Aesth PlastSurg 2009;33:770-3.

20. El-Ali K, Dalal M, Kat CC. Modified C-V flap for nipple reconstruction: Our results in 50 patients. J Plast Reconstr Aesthet Surg 2009;62:991-6.

21. Weinfeld AB, Somia N, Codner MA. Purse-string nipple areolar reconstruction. Ann Plast Surg 2008;61:364-7.

22. Tatlidede S, Yesilada AK, Egemen O, Bas L. A new technique in nipple reconstruction dome technique with double pedicle. Ann Plast Surg 2008;60:141-3. 